\title{
Development of Game-Based Basic Motion Learning Models for Elementary School Students
}

\author{
Gusnani*, Zalfendi, Erizal N, Nurul \\ Ihsan \\ Sports Education Study Program S2 \\ Faculty of Sports Sciences \\ Padang State University \\ gusnani552@gmail.com
}

\begin{abstract}
The purpose of this study is to produce a learning model that is valid, practical and effective. This type of research is research and development using the development model of Borg and Gall that involved 60 students. Model development is carried out through three stages of testing namely, expert validation, effectiveness testing, and practicality testing. The results of this study were 1) validation was obtained on average by $76 \%$, meaning that the game-based basic motion learning model developed was in the valid category, 2) practicality was obtained at $90.67 \%$, meaning that the product developed was very practical to be used in basic motion learning, 3) the effectiveness was carried out using an experimental design (t-test with a significant level $\alpha=0.05$ ), small scale test results before using the model obtained student learning outcomes $\mathbf{7 1 . 4 1}$ and after using the model an increase in learning outcomes to 82.20. this shows that there is a difference between the acquisition of student learning outcomes before using the model and after using the learning model, so it can be concluded that the model is effectively used in Physical Education and Sports in Class IV Elementary School.
\end{abstract}

Keywords-Learning Model, Elementary Motion, Games, Elementary School.

\section{INTRODUCTION}

As stated [1] that Physical Education is an educational process that utilizes physical activities that are planned systematically aimed at improving individuals,organically, neuromuscularly,perceptually, cognitive, socially and emotional. [2] Learning Physical Education, Sports and Health One of the goals is to improve the ability and basic movement skills. This is in accordance with the Sports and Health Physical Education curriculum explained in Permendiknas No.22 2016 which consists of Spiritual Competitions (KI 1), social competencies (KI 2), knowledge competencies (KI3) and skills competencies (KI4).

According Pangrazi in [3] states that basic motion skills are very important to learn at an early age, because if not enough is taught about basic motion skills, children will experience various obstacles in learning and doing various movement skills that are more difficult in the future, such as learning skills sports techniques. In line with the opinion of Corbin (1980) that childhood is a period of smoothing basic movement skills, so that this time, according to him, is a critical time for learning basic motion skills.

In accordance with the Sports and Health Physical Education curriculum in Primary Schools, the basic movements studied consist of, locomotor basic movements, non-locomotor basic movements and manipulative basic movements. Locomotor motion is the movement of moving from one place to another, such as road, run, and jump. Nonmotomotor basic motion is a movement in place, such as swinging, bending, bending and so forth, while the manifulative movement is a movement of throwing, kicking, dribbling, hitting and so forth.

[4] states that basic mobility can be absorbed in various games, sports, and physical activities that are carried out every day. Through playing activities, it is expected that it is appropriate to develop the basic skills of the elementary school students, because on the basis of the play world activities, besides that also through play activities can provide freshness to the physical and psychological pleasure so that it can create a sense of fun for students in doing movement.

Sports and Health Physical Education which is fun for students can be packaged in the form of play, which is created varies with the aim that children avoid boredom, reluctance, and anxiety which is a form of psychological fatigue so that it can become an attraction for students in following the learning process, especially in learn motion. If learning activities are high and there is already a sense of pleasure for students in learning Physical Education Sports and Health, of course they will use their learning time a lot with movement activities and joy. The impact, students will be rich in motion experience, and motivation arises to carry out physical education activities.

Urich (2000) in [3] explained that Piaget in his writing Intellectual Development Theory (Piaget, 1952) was one of the first figures to emphasize the importance of human motion in relation to the development of knowledge. Gallahue (2010) in [3] states that basic motion skills are grouped into 3 parts, namely: 1) locomotor skills, 2) balance skills and 3) manipulative skills.

[5] stated that the basic ability of movement is an ability that is usually done to improve the quality of life. Basic motion abilities are divided into 3, namely: 1) Locomotor capabilities, used to move the body from one place to another, such as jumping and jumping; 2) non-locomotor capabilities, carried out in a place without adequate room for movement, for example pushing, pulling, swinging, bending, etc. 3) manipulative abilities involve more the ability of hands and feet. 
From some of the opinions above can be interpreted that the basic ability of motion is the ability and ability to be able to make changes in place, position, and speed of the body or parts of the human body that occur in a dimension of space and time that can be observed objectively.

[6] states that human motion is essentially built by four basic components, namely cognitive, motor, affective, and emotional. These four basic components interact with each other in their appearance. Therefore, motion is the implementation of the interaction of the four components which is realized in the real form, namely motion.

According [6] The process of the occurrence of wrong motion can be explained through one of the relevant theories, namely the cibernetic theory. Theibernetic theory is a theory that is developed based on theories that process information, while the analysis is based on theories of psychology, anatomy, physiology and biomechanics.

The problem for learning Physical Education Sports and Health in Elementary Schools is the absence of a variety of play activity models for basic motion learning especially for fourth grade students of elementary schools. Based on the above problems, researchers assume the need for varied game models in the basic motion learning process in Elementary School IV. The forms of the game are expected to have carried out validity tests, practicality tests and effectiveness tests, this is done by carrying out development research using steps scientific development steps. [1] states that development research is a form of pragmatic research that provides a way to test theories and validate habits that have been enshrined through academic tradition. In addition, research development is also a way to produce technical procedures, and tools based on analysis, methodical of a problem.

Joyce in [7] revealed that the learning model is a plan that can be used for the curriculum (long learning material), design learning materials, and to deliver learning inside and outside the classroom. Learning models are conceptual frameworks that describe systematic procedures in organizing learning experiences, to achieve certain learning goals and serve as guidelines for learning designers in planning and implementing learning activities [8].

Learning model is a plan or pattern that can be used as a guide in implementing learning, designing materials, and guiding teacher actions in classroom learning settings or other settings. Learning model development is a series of processes or activities that are carried out to produce a learning model based on existing development theories. learning is also a learning pattern that includes approaches, methods, strategies, and learning techniques used by teachers to achieve planned learning goals.

In compiling the learning model is based on observations of the implementation of science in everyday life which aims to facilitate the delivery of knowledge and life values to be able to be understood and easily applied by students. Referring to the explanation of [9] elements that must be considered by the teacher in choosing a model, namely:

1) Consideration of the objectives to be achieved.

2) Considerations relating to learning materials.

3) Considerations from the point of view of students or students.
4) Other considerations that are non-technical.

[10] In addition to paying attention to things that are rational and theoretical, objectives and results to be achieved, learning should have basic principles in developing models, namely: (1) Syntax, are operational steps of learning, (2) Social system, is the atmosphere and norms that apply in learning, (3) Principles of reaction, is a picture of how teachers should view, treat, and respond to students, (4) Support systems, are all plans, materials or learning environments that supports learning, and (5) Instructional \&naturanteffect, are learning outcomes obtained directly based on the objectives being targeted (instructional effect) and learning outcomes beyond the targeted (nuturanteffect). carried out and fulfilled in shaping a good and correct model development and model development is expected.

In research on the development of basic motion learning models through this game, the products developed are aligned with the basic competencies that exist in the Sports and Health Physical Education curriculum 2013 class IV Elementary School. The curriculum objectives include four competencies, namely spiritual attitude competency, social attitude, knowledge, and skills.Based on the core competencies and basic competencies above, it can be concluded that PJOK material in class IV Elementary School focuses on basic motion (locomotor, non-locomotor and manipulative motion) as a major part in the physical and sports physical education process. Therefore, the relationship between core competencies and basic competencies with research on the development of gamebased basic motion models is assumed to be able to fulfill all aspects needed from these competencies.

\section{RESEARCH METHODOLOGY}

This study uses a research and development approach (research and development), using a development model developed by Borg And Gall, which consists of ten development steps.

This research was conducted in several State Primary Schools in Kecamatan X Koto Diatas including Public SDN 09 BalaiSelasaSibarambang, SDN 01 Paninjauan and SDN 03 TanjungBalit. The research was conducted in May - July 2019.In collecting data in this study use instruments in the form of evaluation sheets and questionnaires. The factors seen are validity, practicality and effectiveness of the product itself.

The data analysis technique used in this research development is to use a descriptive percentage analysis technique.

\section{A. Research Results}

\section{RESULTS}

\section{Preliminary Research}

The results of the preliminary research are a reference for researchers to develop the model to be carried out. The preliminary study was conducted on 15 State Primary Schools in District X Koto Above through the distribution of instruments in the form of a questionnaire of 16 questions. Based on respondents 'answers to the distributed questionnaire results obtained in the implementation of Physical and Physical Education learning seen from the 
teacher's preparation in designing learning shows that the learning provided has not varied, this is indicated by the results of respondents' answers from 15 teachers, only 1 person $(6,67 \%)$ who provide learning in the form of various games, while $93.33 \%$ said that learning Physical Education Sports and Health have not used various forms of play.

\section{Product Planning and Development}

At the planning stage the researcher takes a number of steps, to determine the forms of the game model that will be developed. In this case the researcher made 1) the selection of core competencies, basic competencies, and developed the indicators, 2) identified the forms of basic motion learning that would be used including games containing locomotor motion elements, non-motomotor motion, and manipulative motion, 3) designing learning steps which will be developed, 4) identify the realm of attitude to be developed, including fostering cooperation, self-confidence, interests, talents, motivation, and active participation in games, 5) Identifying safety rules at school, 6) designing forms of play, rules games, game techniques used, and language selection that are easy to understand and understand. The results of this stage are the initial draft of a basic motion learning model through games for grade IV students of elementary schools that are ready to be validated by experts.

\section{Expert validation}

The initial draft of the finished product is prepared, then consultations and guidance with experts is carried out in accordance with their respective fields of science. In this validation the researcher used two experts namely learning model expert and Prof. Dr. Gusril, M.Pd and language expert Prof. Dr. Ermanto, M.Hum. products developed through the filling of instruments that have been provided. Based on the results of expert validation obtained an average of $76 \%$, meaning that expert judgment on the learning model designed can be categorized valid.

\section{Trial in Small Groups}

A small-scale trial of the researcher was carried out at 09 elementary school on Tuesday Sibarambang District X Koto Diatas. The number of samples is 22 people. The purpose of this small-scale trial is to obtain information on whether the game-based basic motion learning model for grade IV elementary school students is effective or not. In this case the researchers used an experimental design (before-after).

Based on the results of trials conducted by researchers obtained student learning outcomes by using a game-based basic motion learning model an increase that is before using the model the average value of students is $71 \%$ and after using the model an increase in learning outcomes to $82 \%$. This means that student learning outcomes after using the model compared to before using the model an increase, based on these results it can be said that the product in the form of a game-based learning model is declared effective.

\section{Product Revision}

Based on the results of small-scale trials conducted there are several things that must be improved according to the input provided by students directly at the time of the trial, including:

a) The distance in the game developed is even farther away. This was done with the "Great Service" playing model, which was originally made at a service distance of 4 meters from the net to 5-6 meters from the net.

b) In the "Boom Ball" Game, initially using 2 balls, problems that arise, students are a bit confused in playing, so it is suggested to be reduced to one.

6. Main field testing.

The field test, will be carried out a practicality test, using 2 observers who are physical and physical education teachers at the research site. Based on practicality test, using observation sheets that are in accordance with the implementation of learning in the 2013 curriculum. The assessment was carried out by 2 observers, with the results obtained an average of $90.67 \%$, it can be concluded that based on the results obtained showed a game-based basic motion learning model very practical to use in learning PJOK.

\section{Product revision II}

Based on the input and suggestions from the observer on product deficiencies in field tests or large scale tests, improvements are made and then the product can be said to be final.

8. Product Dissemination and Distribution

The final product will be published and introduced in journals and teacher discussion forums such as KKGO teacher training MGMP / MGMP.

\section{Model Feasibility}

\section{Expert Validation Results}

The results of the expert / expert assessment of the gamebased basic motion learning model is $76 \%$ which is in the valid category. It can be interpreted that the game-based basic motion learning model for grade IV elementary school students is valid and can be used in learning.

\section{Product Practicality Results}

Practicality tests are carried out during large-scale tests. Practicality test involves two observers as assessors, using instruments that have been provided by researchers. The practicality of the developed learning model can be seen from the observation sheet of the learning implementation. The results of observations of the implementation of learning obtained an average of $90.67 \%$.

\section{Model Effectiveness}

The effectiveness of the learning model seen from student learning outcomes. Assessment of student learning outcomes consists of the realm of attitude (affective), knowledge (cognitive), and skills (physicomotor) which are carried out through processes and results. The assessment process is seen from the activities of students while participating in learning such as their attitudes and skills. While the assessment of results is an assessment relating to student understanding of the material obtained at the end of learning.

a) Effectiveness Test Results on Small Scale i. Learning Outcomes of Attitude Domains

Based on the learning outcomes data obtained, the results of the t test calculation shows that the t-value $=$ 10.05 while the t-value is 1.725 with a sign level a of 0.05 . T value is smaller than table $(-10.05<1.725)$ It was concluded that there were significant differences in 
student scores before and after using a game-based basic motion learning model.

ii. Knowledge Learning Outcomes

Based on the t test calculation, it can be seen that the $\mathrm{t}$-count $=-17.75$ while the $\mathrm{t}$-value is 1,725 with a sign level $(\square)$ of 0.05 . $T$ value is smaller than $t$ table $(-17.75>$ $1,725)$. It was concluded that there were significant differences between the learning outcomes of the knowledge domain before and after using a game-based basic motion learning model in class IV Elementary School.

iii. Skill Learning Outcomes

Based on the results of the test calculation it can be seen that the $\mathrm{t}$-count $=-12.50$ while the $\mathrm{t}$-value is 1.725 with a sign level $(\square)$ of 0.05 . T value is smaller than $t$ table $(-12.50<1.725)$. It was concluded that there was a significant difference between the learning outcomes of the realm of skills before and after using a game-based basic motion learning model in grade IV Elementary School.

b) Effectiveness Test Results on a Large Scale i. Learning Outcomes of Attitude Domains

Based on the average learning outcomes for the realm of attitude of 38 students before using a game-based basic motion learning model is 78.42 while after using a game-based basic motion learning model there is an increase in the average value to 86.05 with good predicate. In the results of the $t$ test calculation it appears that the $\mathrm{t}$-value $=-16.96$ while the $\mathrm{t}$-value of 1,688 with a sign level (a) of 0.05 . $\mathrm{T}$ value is smaller than t table $(-16.96<1,688)$. This shows that there are significant differences between the learning outcomes of the realm of attitude before and after using a game-based basic motion learning model in grade IV Elementary School.

\section{ii. Knowledge Learning Outcomes}

Based on the average learning outcomes of the knowledge domain before and after using a game-based basic motion learning model in grade IV Elementary School is significant. In the results of the test calculation it appears that the $\mathrm{t}$-value $=-19.50$ while the $\mathrm{t}$-value of 1,688 with a sign level (a) of 0.05 . $\mathrm{T}$ value is smaller than t table $(-19.50<1,688)$. It was concluded that there were significant differences between the learning outcomes of the knowledge domain before and after using a game-based basic motion learning model in class IV Elementary School.

iii. Learning Outcomes Skills

Based on the average value of the skills show that the correlation between the two average learning outcomes of the realm of skills before and after using a game-based basic motion learning model in class IV Elementary School is significant. In the results of the $t$ test calculation it appears that the $\mathrm{t}$-value $=-20.00$ while the $\mathrm{t}$-value of 1,688 with a sign level (a) of 0.05 . $\mathrm{T}$ value is smaller than t table $(-20.00>1,688)$. It was concluded that there were significant differences between the learning outcomes of the realm of skills before and after using a game-based basic motion learning model in class IV Elementary School.

\section{DISCUSSION}

The development of game-based basic motion learning models for grade IV elementary school students serves as a tool in the implementation of learning. This learning model is expected to help teachers and students in implementing PJOK learning in elementary schools, especially in class IV, so that the objectives of learning can be achieved by obtaining good learning outcomes.

Based on the instruments given to experts, a validation result of $76 \%$ was obtained, this means that the products produced in this study according to the expert were declared valid. Practicality test (usability) of the developed model seen from the results of the implementation of product deployment.

The results obtained from the product usability test in the form of developing a game-based basic motion learning model for fourth grade students in elementary school, practitioner 1 gave an assessment of 90.22, these results indicate that the use of the product is categorized as very practical, practitioner 2 gives an assessment of 91.11, these results indicate that the use of products categorized as very practical. Based on the assessment of the two practitioners can be averaged so that the results obtained by 90.76 with a very practical category.

Based on the average results of the feasibility of the model, it can be concluded that the use of the product in the form of a game-based basic motion learning model for basic motion learning in fourth grade students of elementary schools is very practical.

Based on the results of small-scale trials showed that an increase in student learning outcomes from an average of 71 increased to 82. In large-scale tests also increased student learning outcomes from an average of 74 increased to 87 , it can be concluded that the use of learning models in gamebased basic motion material is very effective in improving student learning outcomes, especially in basic motion learning in class IV Elementary School.

\section{CONCLUSION}

Based on the development and testing of learning models that have been conducted, the following conclusions are obtained:

1. A product that has been produced in the form of a gamebased basic motion learning model for elementary school students is valid, the results of an expert validator's evaluation are $76 \%$.

2. Based on the results of the practicality test of a gamebased basic motion learning model for Elementary School students classified as very practical with a percentage of assessment of $90.67 \%$.

3. Based on the results of the analysis on the effectiveness test, it is obtained that the game-based basic motion learning model is very effective in improving student learning outcomes in the realm of attitudes, knowledge, and skills.

Based on research that has been done, some of the writer's suggestions addressed to: 
1. The Government, especially the Solok Regency Youth and Sports Education Office, is able to conduct training for PJOK teachers, especially on developing models in learning.

2. Principal, the school should be expected to always support activities that can improve PJOK teacher competency.

3. Elementary School PJOK Teachers, based on the results of the validity, practicality, and effectiveness that have been implemented, this Basic Game Based Learning Model can be used as an alternative in teaching basic motion learning material especially for grade IV students in Primary Schools.

4. Other researchers, can develop Game-Based Basic Motion Learning Models in other material and further in the wider scope of the school with different situations and conditions to get more perfect results.

\section{REFERENCES}

[1] Gusril. "Perkembangan Motorik Pada Masa Anakanak". Padang:UNP Press. 2016, pp. 36.

[2] BNSP. "Standar Kompetensi dan Kompetensi Dasar Pendidikan Jasmani, Olahraga, dan Kesehatan Sekolah Dasar dan Madrasah Ibtidaiyah". Jakarta: Kemendikbud. 2005, pp. 48.

[3] S. Bakhtiar. "Perkembangan Motorik Anak-anak dan faktor yang Mempengaruhinya". Jurnal Forum Pendidikan. No:03. 1995, pp. 89.

[4] R. Lutan. "Olahraga dan Etika FairPlay". Jakarta: Depdiknas. 2001, pp. 56.

[5] S. Ma'mun. "Perkembangan Gerak Dan Belajar Gerak”. Jakarta: Depdiknas. 2000, pp. 46.

[6] Kiram. "Belajar Keterampilan Motorik". Padang: UNP Press. 2016, pp. 87.

[7] Y. Elly. "Pengembangan Model Pembelajaran Lompat Jauh Pada Siswa Sekolah Dasar" diunduh tanggal 26 Januari 2019. 2013, pp. 55.

[8] J. Malau. "Model-model Pembelajaran", Disajikan pada saat lokakarya peningkatan kempetensi teknis guru dalam pengembangan model pembelajaran dan penyusunan soal ujian angkatan II (Fisika Madrasah Aliyah) Pusdiklat Tenaga Teknis Keagamaan. Pada Tanggal 07 Februari 2006. DKI Jakarta. 2006, pp. 41.

[9] Rusman. "Model - model Pembelajaran Mengembangkan Profesionalisme Guru (2 ${ }^{\text {nd }}$ ed)". Jakarta: Rajawali Pers. 2012, pp. 32.

[10] H. Rahyubi. "Teori-Teori Belajar dan Aplikasi Pembelajaran Motorik". Majalengka: Nusa Media, 2012, pp. 25. 